\title{
Seasonal Capacity Scaling and Learning Centres
}

\author{
Henrik Køhler Simonsen ${ }^{1}$, Dennis Grauslund ${ }^{2}$ \\ ${ }^{1}$ CBS \& SmartLearning, Denmark, ${ }^{2} \mathrm{UCN}$, Denmark.
}

\begin{abstract}
Danish politicians' interest in using higher education institutions (HEIs) as policy instruments in regional development initiatives has increased significantly in recent years. Recent initiatives include the establishment of regional learning centres and study stations. This article has two overall research objectives. The first objective is to discuss the use of regional learning centres and study stations and to discuss an overall conceptual framework for the establishment and running of physical and virtual learning centres or study stations. The second objective is to discuss the use of seasonal capacity scaling in the educational sector. The discussion is based on a concrete case from a regional area of Denmark supplemented with interviews of both students, teachers and programme managers. Our research shows that seasonal capacity scaling of educational offerings based on a combined physical and virtual framework may be beneficial when establishing and running learning centres or study stations.
\end{abstract}

Keywords: Learning centre; study station; scaffolding; seasonal capacity scaling. 


\section{Introduction}

In recent years, there has been an increasing interest in using HEIs as policy instruments in regional development initiatives. Recent studies have shown that young adults situated in rural areas relocate themselves in order to obtain a degree from a HEI, however, they often decide not to return to their place of birth, cf. Hansen (2014) and Larsen (2017). This is problematic as companies in rural areas may find it difficult to attract skilled labour, which may lead to a stagnation in growth for said companies, cf. OECD (2017).

\section{Case Description \& Methodology}

In this section of our paper, we will outline our case study and our methodological considerations. Our case is Skjern, which is one of the main cities in Ringkøbing-Skjern Municipality, which geographically speaking is the largest municipality in Denmark. Ringkøbing-Skjern Municipality is located on the west coast of Denmark with the North Sea as a main attraction for the thousands of tourists who visit the area each year. Tourism is one of the main drivers of value creation in Ringkøbing-Skjern Municipality, with $7.4 \%$ of the value created coming from the tourism and hospitality industry. This is significantly above the average in Denmark, which only is $3.2 \%$, cf. VisitDenmark (2017). The tourism and hospitality industry is therefore important for the continuing development of RingkøbingSkjern Municipality. The destination of Ringkøbing-Skjern has experienced growth in recent years, and this growth is expected to continue in the coming years. This calls for an "educational upgrade" of the existing and the future labour force, if SMEs within the destination should experience the full benefits of future growth. The methodology is a concrete case from a regional area of Denmark supplemented with interview data from interviews with decision makers, students, teachers and programme managers.

\section{Learning Centres and Study Stations}

In this section of our paper, we will outline existing definitions and theoretical considerations on learning centers and study stations. First, we will define and discuss the term 'learning centres'. The term 'learning centre' is complex in nature, and existing literature contains different understandings and different definitions. One definition of 'learning centres' in Scandinavia uses four design principles on learning centres as follows, cf. Petersen et al. (2016):

a) A learning centre is a physical location, where citizens can meet other citizens who also wish to study. A learning centre does not comprise an online platform or an online education portal only. 
b) A learning centre connects to education institutions through digital couplings. These couplings may take different forms, including synchronous telepresence or asynchronous learning platforms. The central premise is that the couplings connect the learning centre to one or more education institutions.

c) Teaching at a learning centre takes place through the digital couplings described above. That is, the teachers are not physically present at the learning centre, but various resource staff members may work there, such as mentors, career counselors and technical assistants.

d) A learning centre is rooted in the local community and owned by the municipality. This means that the municipality is in charge of running the learning centre, whereas the education institutions are responsible for offering courses by connecting digitally to the learning centre. The municipality defines the objectives and the design of the learning centre as well as the facilities available.

This definition was very useful, because it enabled us to develop our own model. Petersen et al. (2016) base their definition on the 3M functions originally suggested by Grepperud \& Thomsen (2001). The 3M functions can be used as a general design framework for learning centres and these functions are a Motor, a Mediator and a Meeting Place. The Motor means that a regional learning center may act as an organizational motor for local development, the Mediator function means that the local learning center in fact is a mediating factor between local demand for competencies and educational needs. Finally, the Meeting Place means that the learning center is both a physical and a virtual place, in which students, teachers and mentors meet. Establishing a good relationship between students and especially teachers is important, as it affects students' successful study progress, cf. Hagenauera \& Voletb (2014). Therefore, the Meeting Place and how it enables students and teachers to interact with each other and build relationships are of great importance.

Second, we will define and discuss the term 'study stations'. According to a Ministerial Order, cf. UFM (2018) by the Danish Ministry of Higher Education and Science and a number of other orders by the Ministry, a study station may be described as an opportunity for Danish University Colleges and Business Academies to place (or distribute) educational offerings in areas, where the provision of educational offerings is low and the demand for specially trained labour is high, cf. UFM (2018).

Study stations thus seem to be much more embedded in the local business community and offer an interesting opportunity for HEIs and municipalities to educate and retain talents in rural areas of Denmark. There are a number of learning centres in Denmark already, for example HUSC, cf. Kristiansen (2018), which is a learning centre rooted in the local community and owned by the municipality, cf. item D in Petersen et al. (2016). HUSC may thus be characterized as a learning center with an active mediator. 


\section{Conceptual Framework and Discussion}

In this section, we will outline and discuss our conceptual framework for physical and virtual learning centres \& study stations, because we believe that innovation in this area is needed. We have based our framework on the literature discussed and on our case. Our framework presents a new and alternative view on learning centres and study stations. Our framework includes considerations on the correlation between the student, the learning objectives, the study activities, the learning activities, the scaffolding activities and the role of the stakeholders. We have developed the following model shown Figure 1, which illustrates our framework.

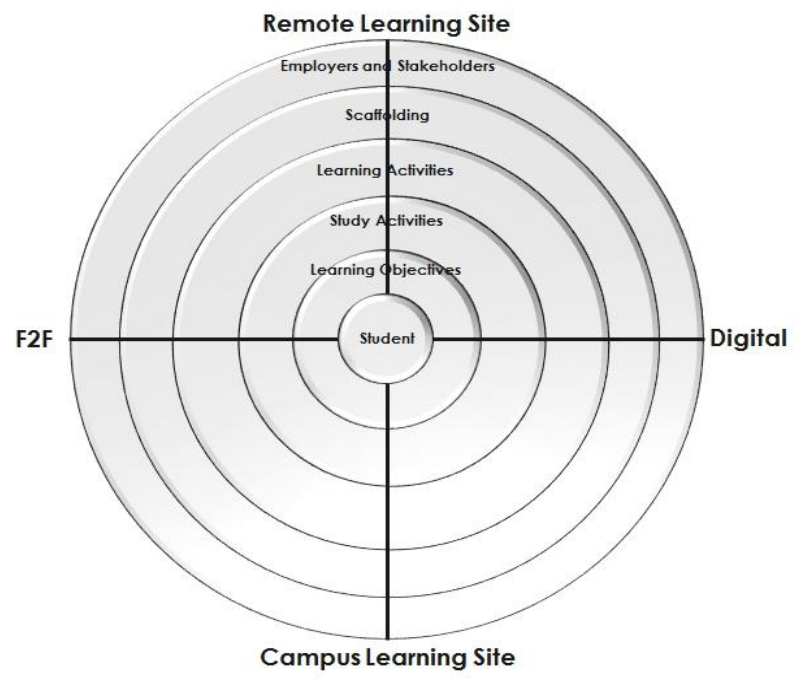

Figure 1. Model on learning centres and study stations

The model above takes its starting point in two scales. When setting up a learning centre or study station, it is first recommended to consider the horizontal continuum between F2F learning, i.e. conventional classroom teaching and digitally supported learning, i.e. learning by means of online learning activities. In our opinion, it is important to consider how the learning centre in question should be placed on this blended learning scale, and perhaps even more important how the two approaches can support the student and his/hers learning objectives. Second, the vertical scale between campus learning, i.e. when learning primarily takes place on a campus and a remote learning site, i.e. where learning takes place at home, in the train, in the workplace etc. We argue that the conceptual framework developed here will successfully facilitate most decisions in the design phase of any learning center or study station. The framework applies for both physical and virtual learning centres and study stations and as such, we do not distinguish between the two, because we see them as fully 
integrated. In our framework, the student thus has access to both a physical and a virtual learning centre or study station thus enabling the student to learn anytime and anywhere.

Furthermore, our model also encompasses a number of other considerations. At the center of the onion-like model is the student, i.e. we must base our learning design on an in-depth analysis of the student characteristics in order to cater for the needs of this particular student in the best possible way. Obviously, this is closely linked to the next layer in our model, which is the learning objectives. Without clear learning objectives, it is very difficult to develop successful learning designs. The third layer is the study types, i.e. Acquisition, Collaboration, Discussion, Investigation, Practice or Production, which are part of the Arena Blended Connected Curriculum Design, cf. Perovic (2015). The fourth layer is the learning activities. Learning activities are the concrete activities (either F2F or digital) that teachers plan to carry out with the students in order to reach the learning objectives. The fifth layer is scaffolding, i.e. the types of support activities and support structures that are required to scaffold the students and the teachers in question.

Based on our case study this is particularly important because learning centre and study station students naturally need scaffolding to be able to study from a learning centre or study station. We recommend an active mediator, cf. also Hattinger et al. (2007) and we recommend that the learning centre or study station in question should be supported by receptionists, mentors or at least teaching assistants, because it is an effective way to support rural learners. In other words, human scaffolding is an important element. The final and sixth layer is the employers and/or stakeholders. The local employers and stakeholders are crucial for the success of learning centres and study stations. Local employers should be involved as natural co-creators in the learning activities in the learning centre or study station in question as they also hire the students when they graduate. Furthermore, the involvement of local employers and stakeholders ensures continued relevance of the supplied education. Local anchorage and involvement of local decision-makers are crucial for success.

When setting up a learning centre or study station we also suggest that a seasonal capacity scaling approach is used. Our model on seasonal capacity scaling in education is shown in Figure 2 below. 


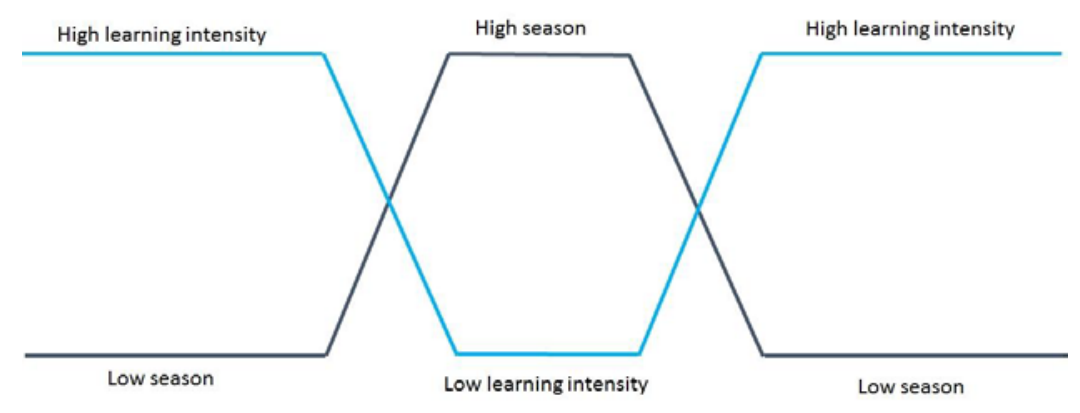

Figure 2. Model on seasonal capacity scaling in education

The seasonal capacity scaling model is based on four design principles. The first underlying principles in our model is that we want to supply education to the right type of students, in the right geographical area, at the right time and at the right amount and quality. Another underlying principle in our model is that we want to design educational offerings that are fully integrated with a specific industry (in our case the tourism and hospitality industry) in a specific region (in our case Ringkøbing-Skjern). The third underlying principle in our model is that we want to design cost-effective educational offerings, which fully utilize the financial benefits of seasonal capacity scaling. The fourth underlying principle in our model is that we want to design educational offerings, which successfully support the regional stakeholders by allowing students to work full time during high season (in the Danish tourism and hospitality industry peak season is May-August). Interview person 3, who is a representative from the Confederation of Danish Industry strongly supports this model and says "this would be very interesting for our members, especially in the service industry and I think that it would be a good idea especially in continuing education". This means that we have developed a model, which calls for a flexible educational offering, where learning intensity is high when the related industry in question is in low season and vice versa. As seen in Figure 2 above, we propose a flexible form of study, which allows students to work full-time in a period of four months during high season in the industry in question (in this case the tourism and hospitality industry) and when the industry is in low season the formal learning intensity at the learning center or study station is increased. This is in fact supported by interview person 1 , who is a student. He says that "I think it would be a very good idea to learn more during off season and then use your new knowledge during peak season. I would in fact also be willing to be enrolled in such a programme even though the total study length would be longer. So I would not mind a longer study period" when asked about the seasonal capacity scaling model.

The idea of using a seasonal capacity scaling model is also supported by interview person 2, who is an educational expert from one of Denmark's largest unions. She says “it does make 
sense in a Life Long Learning perspective and especially in continuing education. However, I do not think that it works in traditional full time programmes”.

By accommodating the need for labour during peak season, local stakeholders should support the idea of providing education that may benefit said stakeholders in the future, as a better educated labour force will create more value. Furthermore, this flexible approach to formal education makes education much more practice-relevant for the students and it is in fact also an economic approach to educational provision. Education is hard business and the fixed costs are high, no matter how many students the HEI in question has in each class. Therefore, HEIs need to design for full capacity utilization where some programmes have high learning intensity in periods where other programmes have low learning intensity.

Based on our case and on the basis of our research developing this framework, we believe that the advantages or gains of using this framework are considerable. We argue that our framework would mark the beginning of a new era in the Danish educational sector, because it would be a considerable gain for the local industry, the local students, the local economy, the HEIs and the societal cohesion of the Danish society. Furthermore, we also find that when educational offerings are integrated in the local community and in the local business, important innovation is facilitated and often such collaboration leads to professional clusters.

\section{Conclusions}

This article discussed a conceptual framework for learning centres and study stations. The conceptual framework consisted of two models; one on learning centres and study stations, and one on seasonal capacity scaling of education. Our discussion was based on a specific case from Rinkøbing-Skjern and five interviews with both decision-makers, students, teachers and programme managers. Based on the analysis we argue that the framework developed is applicable to a case such as Ringkøbing-Skjern and based on our data we believe that our framework is indeed beneficial when designing, implementing and running regional learning centers and study stations. We argue that our model on learning centres and study stations addresses some of the most important considerations, because it encompasses several important considerations such as the student, the learning objectives, the study activities, the learning activities, the scaffolding of both teachers and users and the role of the employers and the stakeholders.

Based on the analysis we also argue that our framework enables students in the tourism and hospitality industry to earn a degree while at the same time meeting the employers' demand for high season employment, because the framework developed uses a seasonal capacity scaling approach allowing students to work full-time in high season and study full-time in low season. We argue that the seasonal capacity scaling model is a huge step in the right direction, because learning should in fact be more in sync with the regional industry in 
question. Additional research in related areas such as for example, time scaling, area scaling, curriculum scaling, platform scaling and network scaling is very much needed in times of disruption in the educational sector.

\section{References}

Grepperud, G. \& Thomsen, T. (2001): Vilkår for et regionalt utdanningsløft -Vurdering av Studiesenteret på Finnsnes 1996-2001. Slutrapport. U-VETT, Universitetet i Tromsø. Høgskolen i Harstad.

Hagenauera, G. \& Voletb, S. E. (2014): Teacher-student relationship at university: an important yet under-researched field, Oxford Review of Education, Vol. 40, No. 3, 370388.

Hansen, S. J. (2014). At komme fra 'udkanten': Om sted, stedsans og unges uddannelsesstrategier i et socialt rum under forandring - belyst gennem et casestudie af Hirtshals, en havneby på den nordjyske vestkyst. Københavns Universitet, Det Humanistiske Fakultet.

Hattinger, M., Hellsten, J-O. \& Snis, U. L. (2007): Lärcentrum - perspektiv och Möjligheter - Analys och praktik. Nationalt centrum för flexibelt lärende. Rapport 1: 2007.

Kristiansen, T. M. (2018): Holbæk Uddannelses- og Studiecenter. In: https://husc.holbaek.dk/om-husc. (Accessed 1 April 2019).

Larsen, K. T. (2017) Laboured learning. Investigating challenged localities through a geography of vocational education (Aalborg: Aalborg University)

OECD (2017): Enhancing the Contributions of SMEs in a Global and Digitalised Economy.

Perovic, N. (2015): ABC (Arena Blended Connected) curriculum design. In: http://blogs.ucl.ac.uk/digital-education/2015/04/09/abc-arena-blended-connectedcurriculum-design/. (Accessed 1 April 2019).

Petersen, A. K, Hestbech, A \& Gundersen, P. (2016): A Design-Based introduction to learning centres. In: Læring \& Medier.

UFM (2018): Videregående uddannelse i flere dele af Danmark. In: https://ufm.dk/aktuelt/pressemeddelelser/2018/videregaende-uddannelse-i-flere-dele-afdanmark. (Accessed 1 April 2019).

VisitDenmark (2017): Turismens økonomiske betydning i Region Midtjylland 2015 (https://www.rm.dk/siteassets/regional-udvikling/ru/publikationer/turisme/turismensokonomiske-betydning-i-region-midtjylland-2015.pdf). (Accessed 1 April 2019). 